\title{
On the removal of chains from the insane. Phillippe Pinel
}

On the abolition of chains for the insane; by Ph. Pinel, membre de l'Institut, etc. (extracted from his notebook and sent for publication by his son, M. Pinel.)

Archives Général de Médicine; May 1823

In the Year 3 of the Republic I abolished the use of chains at the Bicêtre. Pussin was put in charge of the job. We made no other preparation except to have some strong strait-jackets ready. On the first day 12 insane people were set at liberty and allowed to walk around in a strait-jacket. Next day and on the following days chains were increasingly disused.

It may be noted that (prior to the unchaining the patients habitually broke 300 to 400 wooden cups and porridge bowls a month: (prior to the unchaining) the warders often received blows, indeed one was struck by a patient with his handcuffs and had to immediately be trepanned (a hole bored in the skull) which soon led to death. After the abolition of the chains no such frightful events took place. In the Year 6 chains were abolished at the Salpettrière too, with the same successful result.

It may be noted that some patients did not want their chains removed, it seems that they had got so used to having them on. A ship's captain, an Englishman, had been enchained in a continual state of maniacal fury for 45 years but within two days of use of the straitjacket he calmed down. Another officer, enchained for 36 years, who threatened to kill anyone who came into his cell, climbed the stairs perfectly calmly, looked at the sky and exclaimed "how beautiful it was" (previously he was always enchained naked since he always tore his clothes to pieces).

In the first few days it took seven or eight warders to get patients into strait-jackets, but soon four were enough, then two. In the end the patients put themselves into strait-jackets. At Bicêtre patients from all countries were treated ... Dutchmen, Englanders, Prussians etc. In these patients the abolition of the chains did not lead to improvement, probably because they did not speak French, could not make themselves understood, and probably also because they were homesick.

It is very important to note this improvement in the patients: it was a consequence of their liberation and better attitudes; if harsh treatment is used and enchainment continued dangerous hatred builds up leading to vengeful acts when least expected.

I recall, with some amusement, the reaction of the Chief Of Police when he heard that chains at Bicêtre had been struck off. He came to see me and expressed strong opposition; he warned me that I was putting myself at risk, that I was a valued public servant etc etc. In response I took him to see the scene and said that henceforth strait-jackets not chains of iron would be the order of the day.

There are two kinds of strait-jacket, one for restraint and one for punishment. The first is to prevent the patient from injuring himself, it is loose and he walks about wearing it. The other is so constructed that the sleeves are tied behind the body, which leads to restriction of arm movement and a constriction of the chest, so that after 15 minutes the patient begs pardon; it is only to be used for short periods.

Editor's Note: it is hard to believe that 30 years following the abolition of chains at Bicêtre and the Salpetrière there are still hospitals in several countries where this inhumane custom still exists. Can one credit such continuation of barbarism? We hope that this eloquent memorandum will have inspired $\mathrm{Dr}$ Esquirol and those charged with improvement in asylums for the insane will not relax their efforts; we would advise that the model followed at Bicêtre and the Salpettrière should be taken as example.

PINEL, fils

Translated by Philip Snaith, Senior Lecturer, Academic Unit of Psychiatry, St James's University Hospital, Leeds LS9 7TF 